\title{
Editorial
}

\section{Sustainability Science: Progress Made and Directions Forward}

\author{
Barry Ness \\ Lund University Centre for Sustainability Studies (LUCSUS), P.O. Box 170, SE-221 00 Lund, Sweden; \\ E-Mail: barry.ness@lucsus.lu.se; Tel.: +46 462224809
}

Submitted: 17 May 2013 | Published: 21 May 2013

I am honored to contribute an editorial for the inaugural issue of Challenges in Sustainability (CiS). It has provided the opportunity for me to take a step back and reflect on both the developmental progress in the field of sustainability science since its formal launch, now over twelve years ago [1,2], and where the field might head in coming years. While it may always feel that the field is changing too slowly to keep up with the challenges it addresses, the developments have been noteworthy, especially in academia. I will discuss three areas: education, research and institutional development.

The growing offering of sustainability (science) educational programs at all levels has been an important part of the field's evolution. Individual areas of concentration can include business and management, leadership, engineering, or policy management, to name a few. Flagship programs are now found throughout the world, including Arizona State University, Leuphana University of Lüneburg, and the University of Tokyo. In addition, programs at smaller academic institutions such as Furman and Kean Universities in the U.S. have arisen to meet the increasing demand for sustainability education. In Sweden, where I am based, there are international master's programs in sustainability at Uppsala, Stockholm, Malmö, and Lund Universities, as well as Blekinge Institute of Technology. These programs and their different foci, seek not only to increase student knowledge to understand the complexities of sustainability challenges, but also aim to strengthen key competency development [3] in areas such as facilitation and strategic leadership.
In addition to sustainability education, the nature of research projects and programs in the field has also changed. The changes have been driven by both topdown funding priorities to finance research that is more relevant to society, and bottom-up desire from scholars to carry out more integrated work. This has led to the slow evolution from a focus on descriptiveanalytical research, with emphases on understanding the effects of environmental change, to transitional (or transformational) research agendas that embrace working in closer collaboration with societal stakeholders. Such research may concentrate on, for example, envisioning and scenario exercises, or problem-solving strategies beyond change strict policy change $[4,5]$. Transitional sustainability science research is being carried out by individuals in innovative Ph.D. projects focused on single case studies using particular theories and approaches, and by networks of researchers in longer-term programs, such as the Earth System Governance project (www.earthsystem governance.org), united by common sustainable development themes.

To operationalize the education and research agendas in sustainability science, new organizational constellations have developed. Changes have ranged from the creation of new faculty structures at a number of universities, to the establishment of interdisciplinary research schools and programs. The Lund University Centre of Excellence for Integration of Social and Natural Dimensions of Sustainability (www.lucid.lu.se) is just one example of a longer-term program that unites senior and junior staff and Ph.D. candidates from disciplinary backgrounds including 
Economics and Economic History, Philosophy, Physical Geography, Human Geography, Political Science, and Human Ecology. The frequent interactions via discussions, debates, and joint publications have the goal of, amongst others, fostering new professionals who are capable of and accept working with the theoretical and empirical multiplicities [6] often inherent in sustainability education and research.

Despite the advancements over the past decade, there is still much to be done. Continued creativity in restructuring academic disciplines, departments, and funding and tenure incentives are necessary to promote the interaction needed to achieve the interdisciplinary goals of sustainability science. Sustainability issues must also be strengthened in other areas such as the arts and humanities utilizing alternative forms of knowledge dissemination. In the area of education, additional sustainability programs are still needed, but

\section{References}

1. Kates RW, Clark WC, Corell R, Hall JM, Jaeger CC, Lowe I, McCarthy JJ, Schellnhuber HJ, Bolin B, Dickson NM, Faucheux S, Gallopin GC, Grubler A, Huntley $B$, Jäger J, Jodha NS, Kasperson RE, Mabogunje A, Matson $P$, Mooney $H$. Sustainability science. Science. 2001;292(5517):641-642.

2. Kates RW. What kind of a science is sustainability science? Proceedings of the National Academies of the USA. 2011;108(49):19449-19450.

3. Wiek A, Withycombe L, Redman CL. Key competencies in sustainability: A reference framework for academic program development. Sustainability more importantly, there must also be increased efforts in mainstreaming sustainability into all educational programs at different levels. Finally, the field must also continue to place strong emphases on reaching outside of academia in addressing pressing societal challenges.

The launch of Challenges in Sustainability represents an important step in further strengthening the field. The journal's broad aims that focus on systemic analyses of sustainability challenges, solutions and transition processes, and associated trade-offs within socio-ecological systems, will create an important publishing outlet for scholars involved in integrative research. Furthermore, because Challenges in Sustainability is open access, it will mean that the knowledge produced in it can reach a wider range of stakeholders, adding one more attribute in a sustainability science we want to create.

Science. 2011;6(2):203-218.

4. Clark WC, Dickson NM. Sustainability science: The emerging research program. Proceedings of the National Academy of Sciences of the USA. 2003;100(14):8059-8061.

5. Wiek A, Ness B, Schweizer-Ries P, Brand FS, Farioli F. From complex systems analysis to transformational change: A comparative appraisal of sustainability science project. Sustainability Science. 2012;7(Suppl. 1):5-24.

6. Jerneck A, Olsson L, Ness B, Anderberg $S$, Baier M, Clark E, Hickler T, Hornborg A, Kronsell A, Lövbrand $E$, Persson J. Structuring sustainability science. Sustainability Science. 2011;6(1):69-82. 